\title{
Erratum to: Analysis of metabolites in the terpenoid pathway of Catharanthus roseus cell suspensions
}

Mohd Zuwairi Saiman ${ }^{1,2} \cdot$ Natali Rianika Mustafa ${ }^{1,3}$.

Barbora Pomahačová ${ }^{3} \cdot$ Marianne Verberne $^{1} \cdot$ Robert Verpoorte $^{1}$.

Young Hae Choi ${ }^{1} \cdot$ Anna Elisabeth Schulte ${ }^{1,3}$

Published online: 27 May 2015

(C) Springer Science+Business Media Dordrecht 2015

Erratum to: Plant Cell Tiss Organ Cult (2014)

117:225-239

DOI 10.1007/s11240-014-0435-2

There was an error in the third author's name in the original publication. The name is correct in this erratum.

The online version of the original article can be found under doi:10.1007/s11240-014-0435-2.

Natali Rianika Mustafa

mustafa@chem.leidenuniv.nl

1 Natural Products Laboratory, Institute of Biology, Leiden

University, 2300 RA Leiden, The Netherlands

2 Institute of Biological Sciences, Faculty of Science,

University of Malaya, 50603 Kuala Lumpur, Malaysia

3 ExPlant Technologies B.V., Galileiweg 8, 2333 BD Leiden,

The Netherlands 